\title{
EVALUASI IMPLEMENTASI STANDAR NASIONAL PENDIDIKAN PADA PENDIDIKAN INKLUSIF DI SEKOLAH MENENGAH GARUDA CENDIKIA
}

\author{
Ni Komang Kurniawati
}

\author{
Hotner Tampubolon \\ hotnertampubolon@yahoo.com \\ Hotmaulina Sihotang \\ hotmaulina.sihotang@uki.ac.id
}

\begin{abstract}
Abstrak
Penelitian inibertujuan untuk mengevaluasi implementasi penyelenggaraan pendidikan inklusif di Sekolah Menengah Garuda Cendekia, mencakup (1) mendeskripsikan penyelenggaraan pendidikan inklusif sesuai atau tidak dengan delapan standar pendidikan inklusif yaitu standar isi, standar proses, standar kompetensi lulusan, standar penilaian, standar kompetensi guru dan tenaga kependidikan, standarsarana prasarana, standar pengelolaan, dan standar pembiayaan,(2) mendeskripsikan berbagai hambatan dalam implementasi pendidikan inklusif, dan (3) solusi yang dapat dilakukan untuk mengatasi kendala saat penyelenggaraan pendidikan inklusif. Penelitian ini merupakan penelitian jenis evaluasi program dengan pendekatan model Discrepancy (kesenjangan). Penelitian ini dilakukan di Sekolah Menengah Garuda Cendekia. Subjek penelitian adalah kepala sekolah, guru kelas 1-3, dan guru pembimbing khusus. Teknik pengumpulan data menggunakan kuesioner, wawancara, observasi, dan dokumentasi. Hasil penelitian ini menunjukkan bahwa (1) penyelenggaraan pendidikan inklusif belum sesuai dengan delapan standar pendidikan inklusif, yaitu standar isi, standar proses, standar kompetensi lulusan, standar penilaian, standar kompetensi guru dan tenaga kependidikan, standar sarana prasarana, standar pengelolaan, dan standar pembiayaan, (2) hambatan yang dihadapi adalah jumlah Guru Pembimbing Khusus (GPK) yang tersedia masih kurang dan minimnya pemahaman guru reguler tentang pendidikan inklusif, dan (3) solusi yang dapat dilakukan guna mengatasi kendala tersebut adalah GPK memberikan dampingan konsultatif kepada guru reguler, serta GPK dan guru reguler melakukan kerjasama dalam menyelenggarakan pendidikan inklusif.
\end{abstract}

Kata kunci : Evaluasi, Implementasi, Standar dan Inklusi 
Evaluasi Implementasi Standar Nasional Pendidikan Pada Pendidikan Inklusif Di Sekolah Menengah Garuda Cendikia

\begin{abstract}
The purpose of this reseach to evaluate the implementation of inclusive education at Sekolah Menengah Garuda Cendekia, including (1) describing the implementation of inclusive education at Sekolah Menengah Garuda Cendekia according to or not with eight standards of inclusive education namely content standards, process standards, graduate competency standards, assessment standards, teacher and education personnel competency standards, infrastructure standards, management standards, and financing standards, (2) describe various obstacles in the implementation of inclusive education, and (3) solutions that can be done to overcome obstacles when implementing inclusive education. This research is a type of program evaluation study using the Discrepancy model approach. This research was conducted. The research subjects were principals, class 1-3 teachers, and special counselors. Data collection techniques using questionnaires, interviews, observation, and documentation. The results of this study indicate that (1) the implementation of inclusive education is not in accordance with eight standards of inclusive education, namely content standards, process standards, graduate competency standards, assessment standards, teacher competency standards and education staff, infrastructure standards, standards management, and funding standards, (2) the obstacles faced are the number of Special Advisory Teachers (GPK) available is still lacking and lack of regular teacher understanding of inclusive education, and (3) solutions that can be done to overcome these obstacles is special tutor provides consultative assistance to regular teachers, as well as special tutor and regular teachers to collaborate in providing inclusive education.
\end{abstract}

Keywords: Evaluation, Implementation, Inclusive and Standart 


\section{A. PENDAHULUAN}

Penyelenggara pendidikan khusus dapat dilakukan melalui satuan pendidikan khusus, satuan pendidikan umum, satuan pendidikan kejuruan, dan/atau satuan pendidikan keagamaan (Pasal 130 ayat 2 PP Nomor 17 Tahun 2010 tentang Pengelolaan dan penyelenggaraan pendidikan). Penyelenggaraan pendidikan khusus pada satuan pendidikan umum dan kejuruan diselenggarakan secara inklusif. Lahirnya pendidikan inklusif sejalan dengan deklarasi PBB mengenai Hak Azasi Manusia (HAM), yaitu hak pendidikan dan partisipasi penuh bagi semua orang dalam pendidikan. Keberadaan pendidikan inklusif juga didukung oleh deklarasi yang disepakati oleh beberapa negara, termasuk Indonesia, antara lain adalah pernyataan Salamanca tahun 1994 mengenai hak setiap anak untuk mendapatkan pendidikan dan pengakuan terhadap perbedaan minat, kemampuan, dan kebutuhan dalam belajar. Konvensi Perserikatan Bangsa-Bangsa (PBB) yang diadakan pada tahun 2006 telah mendeklarasikan hak-hak anak, dan ditegaskan bahwa semua anak berhak memperoleh pendidikan tanpa diskriminasi dalam bentuk apapun.

Menurut Permendiknas Nomor 70 Tahun 2009 tentang Pendidikan Inklusif bagi peserta didik yang memiliki kelainan dan memiliki potensi kecerdasan dan/atau bakat istimewa, Pasal 1 menyatakan bahwa: Pendidikan inklusif adalah sistem penyelenggaraan pendidikan yang memberikan kesempatan kepada semua peserta didik yang memiliki kelainan dan memiliki potensi kecerdasan dan/atau bakat istimewa untuk mengikuti pendidikan atau pembelajaran dalam lingkungan pendidikan secara bersama-sama dengan peserta didik pada umumnya. Pendidikan inklusif merupakan sistem penyelenggaraan pendidikan yang mewujudkan penyelenggaraan pendidikan yang menghargai keanekaragaman, dan tidak diskriminatif bagi semua peserta didik.

Sementara berdasarkan observasi awal di Sekolah Menegah Garuda Cendikia, tantangan yang dihadapi antara lain, Sekolah Menegah Garuda Cendikia dalam melaksanakan pendidikan inklusif dalam melaksanakan pendidikan inklusif sudah melakukan penyesuaian kurikulum dengan kebutuhan ABK. Peran GPK berperan selain sebagai pendamping juga menyiapkan RPI dalam melaksanakan pembelajaran inklusi. Ketersediaan GPK saat ini ada 12 guru akan tetapi belum pernah mendapatkan pelatihan khusus dalam melaksanakan pendidikan inklusi. Hal ini juga yang menjadi kendala dalam pengelolaan kelas baik secara metode dan model kelas ketika dalam melaksanakan program belajar. Sarana dan Prasana pun masih terbilang kurang memadai bagi beragamnya ABK yang ada di Sekolah Menengah Garuda Cendikia. Keberadaan sekolah ini belum pernah mendapatkan bantuan dari pemerintah khusus untuk pelaksana pendidikan inklusif baik dari segi pembiayaan dan pengevaluasian secara berkala di sekolah ini.

Melihat adanya beberapa kendala yang muncul dalam penyelenggaraan sistem pendidikan inklusif di Sekolah Menegah Garuda Cendikia, di mana perlu dikaji 
kembali standar penyelenggaraan pendidikan inklusif dari sekolah tersebut. Dengan pertimbangan itulah peneliti tertarik untuk melakukan evaluasi terhadap penyelenggaran pendidikan inklusif di Sekolah Menegah Garuda Cendikia. Evaluasi dapat diartikan juga penilaian. Evaluasi atau penilaian adalah penentuan pencapaian tujuan suatu program. Penilaian merupakan suatu bentuk sistem pengujian dalam pelaksanaan program evaluasi untuk mengetahui seberapa jauh kesesuaian penyelenggaraan pendidikan inklusi di Sekolah Menegah Garuda Cendikia.

Evaluasi bertujuan untuk mengetahui secara mendalam apakah terdapat kesenjangan dalam implementasi penyelenggaraan sekolah inklusif di Sekolah Menegah Garuda Cendikia dengan kriteria Standar Penyelenggara Pendidikan Inklusif. Berangkat dari pemikiran ini maka evaluasi terhadap penyelenggaraan pendidikan inklusif di Sekolah Menegah Garuda Cendikia menjadi penting untuk dilakukan guna memperoleh gambaran perbandingan pencapaian program dengan standar mengenai penyelenggaraan pendidikan inklusif bagi anak berkebutuhan khusus di Sekolah Menegah Garuda Cendikia sesuai dengan Standar Penyelenggara Pendidikan Inklusif.

\section{B. KAJIAN TEORI}

UNESCO (United Nations Educational Scientific and Cultural Organiztion) mengemukakan bahwa tujuan praktis yang ingin dicapai dalam pendidikan inklusif meliputi: tujuan yang dapat dirasakan langsung oleh anak, oleh guru, orangtua, dan masyarakat (Tarmansyah, 2007 :111). Pasal 2 Permendiknas No. 70 Tahun 2009 tentang pendidikan inklusi bagi Peserta didik yang memiliki kelainan dan memiliki potensi kecerdasan dan/atau bakat istimewa, dijelaskan bahwa tujuan pendidikan inklusif adalah:

1) Memberikan kesempatan yang seluas-luasnya kepada semua peserta didik yang memiliki kelainan fisik, emosional, mental, dan sosial, atau memiliki potensi kecerdasan dan atau bakat istimewa untuk memperoleh pendidikan yang bermutu sesuai dengan kebutuhan dan kemampuannya.

2) Mewujudkan penyelenggaraan pendidikan yang menghargai keanekaragaman, dan tidak diskriminatif bagi semua peserta didik.

3) Berkembangnya kepercayaan pada diri anak, merasa bangga pada diri sendiri atas prestasi yang diperolehnya.

4) Anak dapat belajar secara mandiri, dengan mencoba memahami dan menerapkan pelajaran yang diperolehnya di sekolah ke dalam kehidupan sehari-hari.

5) Anak mampu berinteraksi secara aktif bersama teman-temannya, guru, sekolah dan masyarakat.

6) Anak dapat belajar untuk menerima adanya perbedaan, dan mampu beradaptasi dalam mengatasi perbedaan tersebut.

Tujuan pendidikan inklusif dapat disimpulkan, adalah memberikan kesempatan yang sama kepada seluruh anak termasuk anak berkebutuhan khusus dalam mendapatkan pendidikan yang menghargai keanekaragaman dan tanpa adanya perlakuan diskriminatif kepada semua peserta didik.

Penyelenggaraan pendidikan di Indonesia pada semua tingkatan didasari oleh Peraturan Pemerintah No. 19 tahun 2005 tentang Standar Nasional Pendidikan. Ada 8 kriteria standar nasional pendidikan antara lain : isi, proses, kompetensi 
lulusan, penilaian, kompetensi guru dan tenaga kependidikan, sarana-prasarana, pengelolaan dan pembiayaan. Pada dasarnya kriteria tersebut memiliki keterkaitan sama lain, yang dapat direfleksikan melalui beberapa topik bahasan, antara lain : kurikulum, kualitas pengajaran, aksesibilitas (non fisik dan fisik), struktur organisasi, kebijakan, jejaring dengan masyarakat dan sistem dukungan jaringan. Anak Berkebutuhan khusus sesuai Peraturan Menteri Pendidikan Nasional Republik Indonesia No 70 tahun 2009 terdiri dari : (a) Tunanetra, (b) Tunarungu, (c) Tunawicara, (d) Tunagrahita, (e) Tunadaksa, (f) Tunalaras, (g) Lamban belajar, (h) Berkesulitan belajar, (i) Autis, (j) Tunaganda, (k) Anak berbakat istimewa, dan (1) Anak korban/pengidap psikotropika.

Selain itu pelaksanaan pendidikan Inklusif juga mengadakan asesmen. Asesmen dapat diartikan sebagai proses untuk mendapatkan Informasi dalam bentuk apapun yang dapat digunakan untuk dasar pengambilan keputusan tentang peserta didik baik yang menyangkut kurikulumnya, program pembelajarannya, iklim sekolah maupun kebijakan-kebijakan sekolah (Nani Triani, 2012:5). Ada 4 (empat) prinsip asesmen, yakni (1) Menyeluruh, (2) Berkesinambungan, (3) Objektif, dan (4) Mendidik.

Setelah dilaksanakan asesmen maka akan di evaluasi program yang sudah dilaksanakan. Beberapa model evaluasi digunakan untuk mengetahui seberapa jauh keberhasilan program yang dilakukan sehingga diperoleh langkah-langkah untuk melakukan perbaikan ataupun pengembangan. Salah Satunya adalah model Evaluasi Dyscrepancy.Kata discrepancy adalah istilah bahasa Inggris yang diterjemahkan ke dalam bahasa Indonesia menjadi "kesenjangan". Model yang dikembangkan oleh Malcom Provus ini merupakan model yang menekankan pada pandangan adanya kesenjangan di dalam pelaksanaan program (Suharsimi \& Cepi, 2014 : 48).

\section{METODOLOGI PENELITIAN}

Penelitian ini merupakan penelitian evaluasi yang dilakukan untuk mendapatkan informasi menyeluruh tentang penyelenggaraan pendidikan inklusif di Sekolah Menegah Garuda Cendikia. Model evaluasi yang digunakan adalah model evaluasi descrepancy yang dikembangkan oleh Provus. Model yang dikembangkan oleh Malcom Provus ini merupakan model yang menekankan pada pandangan adanya kesenjangan di dalam pelaksanaan program (Suharsimi \& Cepi, 2014 : 48). Alasan peneliti menggunakan model evaluasi descrepancy adalah untuk mengetahui, mendeskripsikan danmenginterpretasikan data secara jelas dan rinci tentang implementasi penyelenggaraan pendidikan inklusif, faktor penghambat penyelenggaraan, dan bagaimana upaya dalam mengatasi hambatan penyelenggaraan pendidikan inklusif di Sekolah Menegah Garuda Cendikia.

Model ini merupakan suatu prosedur problem-solving untuk mengidentifikasi kelemahan dan untuk mengambil tindakan korektif. Dengan model ini, proses evaluasi pada langkah-langkah dan isi kategori sebagai cara memfasilitasi perbandingan capaian program dengan standar untuk digunakan sebagai kebijakan di masa depan. Argumentasi Provus, bahwa semua program memiliki daur hidup (life cycle). Karena program terdiri atas langkah-langkah pengembangan, aktivitas evaluasi banyak diartikan adanya integrasi pada masing-masing komponennya.

\section{PEMBAHASAN}


Penyelenggaraan pendidikan inklusif berdasarkan kriteria Standar Penyelenggara Pendidikan Inklusif Sekolah Menengah Garuda Cendikia berdasarkan komponen penilaian terlihat bahwa seluruh perbandingan tingkat pencapaian dengan tingkat kesenjangan lebih besar tingkat pencapaian kecuali pada standar pembiayaan tingkat ketercapaian masih dalam kriteria cukup baik. Tingkat pencapaian kriteria Standar Proses pada penyelenggaraan pendidikan inklusif memperoleh ketercapaian paling tinggi sebesar 78\% dan kesenjangan sebesar $22 \%$. Tingkat pencapaian kriteria Standar Penyelenggara Pendidikan Inklusif paling rendah yaitu berdasarkan komponen penilaian standar isi dan standar proses yang hanya memperoleh tingkat pencapaian sebesar 30,25 \% dengan kesenjangan sebesar $69.75 \%$.

Menurut tingkat pencapaian secara umum, Sekolah Menengah Garuda Cendikia memperoleh $63,72 \%$, termasuk dalam kategori baik. Tingkat kesenjangan dari indikator pencapaian mencapai 36,28 \%.Adanya tingkat kesenjangan sebesar $36,28 \%$. dalam pelaksanaan kriteria Standar Penyelenggara Pendidikan Inklusif dapat diiterpretasikan bahwa ada hambatan dalam penyelenggaraan pendidikan inklusif di Sekolah Menegah Garuda Cendikia. Untuk itu penulis akan paparkan penyebab ketidaktercapaian setiap standar berdasarkan kriteria Standar Penyelenggara Pendidikan Inklusif.

\begin{tabular}{cccccc} 
No & $\begin{array}{c}\text { Komponen } \\
\text { Penilaian }\end{array}$ & $\begin{array}{c}\text { Indikator } \\
\text { pencapaian }\end{array}$ & $\begin{array}{c}\text { Tingkat } \\
\text { pencapaian }\end{array}$ & $\begin{array}{c}\text { Tingkat } \\
\text { kesenjangan }\end{array}$ & $\begin{array}{c}\text { Ketercapaian } \\
\text { kriteria }\end{array}$ \\
\hline
\end{tabular}

\begin{tabular}{|c|c|c|c|c|c|}
\hline 1. & Standar isi & 1.1 & $59 \%$ & $41 \%$ & Baik \\
\hline 2. & $\begin{array}{l}\text { Standar } \\
\text { Proses }\end{array}$ & $\begin{array}{c}2.1,2.2,2.3, \\
2.4,2.5,2.6, \\
2.7,2.8\end{array}$ & $78 \%$ & $22 \%$ & Sangat baik \\
\hline 3. & $\begin{array}{l}\text { Standar } \\
\text { kompetensi } \\
\text { lulusan }\end{array}$ & $\begin{array}{c}3.1,3.2 \text { dan } \\
3.3\end{array}$ & $75,5 \%$ & $24,5 \%$ & Sangat baik \\
\hline 4. & $\begin{array}{l}\text { Standar } \\
\text { penilaian }\end{array}$ & $\begin{array}{l}4.1,4.2,4.3 \text {, } \\
4.4 \text {, dan 4.5, }\end{array}$ & $74,14 \%$ & $25,86 \%$ & Baik \\
\hline 5. & $\begin{array}{l}\text { Standar } \\
\text { kompetensi } \\
\text { guru dan } \\
\text { tenaga } \\
\text { kependidikan }\end{array}$ & $\begin{array}{c}5.1,5.2 \text {, dan } \\
5.3\end{array}$ & $60,6 \%$ & $39,4 \%$ & Baik \\
\hline 6. & $\begin{array}{l}\text { Standar } \\
\text { sarana dan } \\
\text { prasarana }\end{array}$ & 6.1 & $61 \%$ & $38 \%$ & Baik \\
\hline 7. & $\begin{array}{l}\text { Standar } \\
\text { pengelolaan }\end{array}$ & $\begin{array}{c}7.1,7.2,7.3, \\
7.4,7.5,7.6 \\
7.7 \text { dan } 7.8\end{array}$ & $71,27 \%$ & $28,73 \%$ & Baik \\
\hline 8. & $\begin{array}{l}\text { Standar } \\
\text { pembiayaan }\end{array}$ & 8.1 dan 8.2 & $30,25 \%$ & $69,75 \%$ & Cukup baik \\
\hline & Rata-rata & & $63,72 \%$ & $36,28 \%$ & Baik \\
\hline
\end{tabular}

Berdasarkan tingkat pencapaian secara umum, keterlaksanaan kriteria Standar Penyelenggara Pendidikan Inklusif oleh Sekolah Menengah Garuda Cendekia 
mencapai 63,72 \% dengan kesenjangan sebesar $36.28 \%$. Adanya tingkat kesenjangan sebesar $36.28 \%$ dalam pelaksanaan kriteria Standar Penyelenggara Pendidikan Inklusif dapat diartikan bahwa ada hambatan dalam penyelenggaraan pendidikan inklusif di Sekolah Menengah Garuda Cendekia.

Pada standar isi, pelaksanaan kriteria Standar Penyelenggara Pendidikan Inklusif komponen penilaian standar isi memenuhi indikator pencapaian sebesar 59\%. Hal ini disebabkan karena pengembangan kurikulum adaptif dan RPI bagi seluruh ABK belum mampu dipenuhi oleh GPK. Kenyataan yang peneliti temui di Sekolah Menengah Garuda Cendekia ini sesuai dengan pernyataan Bu Wahyu, yang menyatakan bahwa secara umum ketersediaan tenaga pendidik sudah mencukupi, akan tetapi masih ada beberapa kendala seperti, persiapan RPI untuk ABK hanya dilakukan oleh GPK, dan materi pembelajaran yang masih beberapa dari GPK maupun guru mata pelajaran yang membawa materi tambahan untuk ABK dan siswa reguler lainnya. karena sebagian sekolah inklusif belum memperoleh dukungan guru pembimbing khusus maupun tenaga ahli. Sumber daya manusia yang tidak memadai (jumlah dan kemampuan) berakibat tidak dapat dilaksanakannya program secara sempurna, karena mereka tidak bisa melakukan pengawasan dengan baik (Prastiyono, 2013 : 125). Selain itu tidak seluruh siswa berkebutuhan khusus mendapatkan kurikulum adaptif dan RPI membuat sebagian besar anak berkebutuhan khusus yang tidak mendapatkan kurikulum adaptif dan RPI, tidak mendapatkan pembelajaran yang sesuai dengan kebutuhan dan kemampuan belajar anak.

Merujuk pada standar proses, kondisi saat ini Sekolah Menengah Garuda Cendekia dalam kapasitasnya sebagai sekolah penyelenggara pendidikan inklusif belum mencapai standar proses dari kriteria Standar Penyelenggara Pendidikan Inklusif. Pelaksanaan kriteria Standar Penyelenggara Pendidikan Inklusif komponen penilaian standar proses memenuhi indikator pencapaian sebesar $78 \%$. Permasalahan yang muncul dalam pelaksanaan standar proses adalah kurangnya peran guru. Baik GPK maupun guru reguler dalam penyelenggaraan pendidikan inklusif. Menurut Dieni Laylatul Zakia (2015 : 113) Faktor tenaga pendidik (guru) memiliki peran yang sangat besar dalam pencapaian kualitas pendidikan secara umum. Sehingga kurangnya peran guru dalam temuan penelitian ini berdampak besar dalam proses penyelenggaraan pendidikan inklusif di Sekolah Menengah Garuda Cendekia. Faktor penghambat yang muncul pada standar proses tidak jauh berbeda dengan standar kompetensi guru dan tenaga kependidikan, serta standar pengelolaan di mana permasalahan berorientasi pada kurangnya pemahaman guru maupun sekolah dalam penyelenggaraan pendidikan inklusif.

Permasalahan yang muncul dalam pelaksanaan standar kompetensi guru dan tenaga kependidikan adalah kurangnya peran guru baik GPK maupun guru reguler dalam penyelenggaraan pendidikan inklusif disebabkan kurangnya pemahaman guru kelas tentang pengajaran terhadap ABK dan pendidikan inklusif itu sendiri. Sedangkan permasalahan dalam pelaksanaan kriteria Standar Penyelenggara Pendidikan Inklusif komponen standar pengelolaan adalah pelaksanaan kebijakan sekolah dalam hal pengulangan kelas di mana ABK disamakan dengan anak normal.

Apabila dilihat dari temuan-temuan di lapangan, penyebab kurangnya pemahaman guru bukan terletak pada kurangnya pelatihan mengenai pendidikan inklusif, melainkan pada kurangnya kolaborasi antara guru kelas dan GPK dalam 
menyelenggarakan pendidikan inklusif. Sehingga guru kelas tidak memiliki pengetahuan mengenai penerapan pendidikan inklusif itu sendiri. Temuan ini sesuai dengan hasil penelitian yang dilakukan oleh Sunanto dalam Dieni Laylatul Zakia (2015:112) di antaranya menyatakan bahwa: (1) pada awalnya pembelajaran diterima oleh guru kelas, kini bergeser pada ketergantungan pada guru khusus atau guru pendamping. Hal ini menyebabkan kurangnya peran guru dalam pembelajaran bagi ABK. (2) motivasi, kerjasama dalam mengatasi masalah tidak tampak dan tidak dilakukan melalui kolaborasi sebab seluruh aktivitas belajar ABK dari perencanaan, pelaksanaan dan evaluasi diserahkan sepenuhnya kepada guru pendamping. Seyogyanya, guru di sekolah inklusif saling berkolaborasi dalam pelaksanaan program pembelajaran. Sesuai dengan pendapat Sukinah, (2010:45) bahwa guru bekerja dalam tim, guru dituntut melakukan kolaborasi dengan profesi atau sumber daya lain dalam perencanaan, pelaksanaan, dan evaluasi. Sehingga dengan adanya kolaborasi antara guru dengan tim interdisipliner, pembelajaran yang diberikan tidak terkotak-kotak antara anak normal dan anak berkebutuhan khusus melainkan menerapkan pembelajaran terpadu berdasarkan hasil kolaborasi tim interdisipliner. (3)guru pendamping yang berkualifikasi PLB belum memiliki keberanian untuk meluruskan sesuai konsepnya.

Pelaksanaan kriteria Standar Penyelenggara Pendidikan Inklusif komponen penilaian standar kompetensi lulusan memenuhi indikator pencapaian sebesar 75,5 $\%$. Hal ini dikarenakan program pengembangan bakat yang dilaksanakan belum disesuaikan dengan kebutuhan dan kemampuan masing-masing $\mathrm{ABK}$, program masih disamaratakan dengan anak normal. Seyogyanya program pengembangan bakat bagi anak berkebutuhan khusus disesuaikan dengan kemampuan dan kebutuhan masing-masing anak sesuai dengan tujuan pendidikan inklusi itu sendiri. Menurut Paramita Isabella, Emosda, Siratno, (2014 : 55) Pendidikan inklusif juga bertujuan untuk membangun keterampilan dan bakat alamiah yang dimiliki peserta didik. Tentunya keterampilan dan bakat alamiah yang dimiliki masing-masing peserta didik berkebutuhan khusus berbeda-beda. Sehingga program pengembangan bakat seharusnya disesuaikan dengan potensi masingmasing ABK.

Pelaksanaan kriteria Standar Penyelenggara Pendidikan Inklusif komponen penilaian standar penilaian memenuhi indikator pencapaian sebesar $74,14 \%$. Kesenjangan terletak pada guru kelas yang hanya melaporkan perkembangan ABK kepada orangtua murid 2 kali dalam setahun atau setiap pembagian rapor. Laporan perkembangan ABK seharusnya dilaksanakan secara rutin. Menurut Peremendiknas No 20 Tahun 2007 laporan hasil belajar perlu disampaikan kepada peserta didik dan peserta didik yang belum mencapai KKM harus mengikuti pembelajaran remidi. Karena anak harus mengetahui nilai hasil belajar yang didapatnya sehingga anak mengetahui sejauh mana kemampuannya pada saat itu. Selain itu dengan anak mengetahui nilai hasil belajarnya, anak dapat menyiapkan diri untuk mengikuti pembelajaran remedial apabila nilai yang didapat tidak mencapai KKM. Pemberian nilai hasil belajar kepada siswa maupun orangtua ini juga dapat memotivasi siswa untuk dapat meningkatkan kemampuannya dan membuat orangtua dapat mengetahui kemampuan dan perkembangan anak serta memotivasi anak dalam belajar. 
Pelaksanaan kriteria Standar Penyelenggara Pendidikan Inklusif komponen penilaian standar sarana prasarana memenuhi indikator pencapaian sebesar $60,6 \%$. Kesenjangan terletak pada minimnya ketersediaan sarana prasarana dan alat peraga atau media pembelajaran di sekolah. Hal ini dapat disebabkan dengan kurangnya dana dan/atau kurangnya kecakapan sekolah dalam mengelola sarana prasarana yang dibutuhkan sekolah. Berkaitan dengan penggunaan dana, hal ini merujuk kepada pelaksanaan kriteria Standar Penyelenggara Pendidikan Inklusif komponen penilaian standar pembiayaan. Komponen penilaian standar pembiayaan memenuhi indikator pencapaian sebesar 30,25\%. Sekolah Menengah Garuda Cendekia tidak mendapatkan dana bantuan dari Dinas dan tidak mendapatkan dana tambahan dari luar atau dari lembaga swasta. Dikarenakan pihak sekolah tidak berjejaring atau dengan LSM atau lembaga swasta di luar Pemerintah. Menurut Sukinah (2010 : 47) harus ada keterlibatan dan partisipasi orangtua, masyarakat, dan LSM yang lebih luas; harus ada supporting system. Dengan adanya kerjasama antara sekolah dengan LSM, maka bertambahlah partisipan pendukung pendidikan inklusif di Sekolah Menengah Garuda Cendekia. Sehingga dapat membantu mendukung ketersediaan sarana prasarana pendidikan inklusif dan program-program pendidikan inklusif di sekolah.

Berdasarkan kendala yang muncul, diketahui bahwa hambatan utama dalam penyelenggaraan pendidikan inklusif di Sekolah Menengah Garuda Cendekia adalah kompetensi GPK yang tersedia masih belum maksimal dan pemahaman yang guru reguler miliki tentang pendidikan inklusif belum maksimal. Menurut Purwandari (2009) : 7), perlu penyamaan persepsi tentang pendidikan inklusif dari semua elemen, sehingga memiliki pemahaman yang tidak jauh berbeda, dan dapat menyelenggarakan sekolah inklusif dengan prosedur dan langkah yang jelas. Selain itu, hambatan lainnya adalah rendahnya kerjasama antara guru kelas dengan GPK. Purwandari (2009 : 7) menjelaskan bahwa perlu dikembangkan kolaborasi antar tim kerja professional, sehingga dalam menangani ABK dapat diperoleh solusi yang menguntungkan bagi ABK. Dari pendapat di atas menjelaskan bahwa solusi yang tepat dalam mengatasi kendala yang muncul di Sekolah Menengah Garuda Cendekia adalah memberikan pemahaman dan pelatihan kepada guru reguler mengenai pendidikan inklusif. Salah satu caranya adalah GPK memberikan dampingan konsultatif kepada guru reguler, serta GPK dan guru reguler melakukan kerjasama dalam menyelenggarakan pendidikan inklusif.

Berdasarkan hasil pembahasan di atas menunjukkan Sekolah Menengah Garuda Cendekia dalam penyelenggaraan pendidikan inklusif telah mencapai nilai $61 \%$ (kategori baik). Artinya, masih ada Standar Penyelenggara Pendidikan Inklusif yang belum terpenuhi. Sehingga dapat dikatakan bahwa penyelenggaraan pendidikan inklusif bagi anak berkebutuhan khusus di Sekolah Menengah Garuda Cendekia masih terjadi kesenjangan (discrepancy). Serta dari kendala yang muncul, solusi yang dapat dilakukan adalah dengan memberikan pemahaman kepada guru kelas mengenai $\mathrm{ABK}$ dan pendidikan inklusif serta melakukan kerjasama antara guru kelas dengan GPK.

\section{E. KESIMPULAN DAN SARAN}

Berdasarkan tingkat pencapaian secara umum, keterlaksanaan kriteria Standar Penyelenggara Pendidikan Inklusif oleh Sekolah Menengah Garuda Cendekia 
mencapai 63,72 \% dengan kesenjangan sebesar $36.28 \%$. Adanya tingkat kesenjangan sebesar $36.28 \%$ dalam pelaksanaan kriteria Standar Penyelenggara Pendidikan Inklusif dapat diartikan bahwa ada hambatan dalam penyelenggaraan pendidikan inklusif di Sekolah Menengah Garuda Cendekia.

Pada standar isi, pelaksanaan kriteria Standar Penyelenggara Pendidikan Inklusif komponen penilaian standar isi memenuhi indikator pencapaian sebesar 59\%. Hal ini disebabkan karena pengembangan kurikulum adaptif dan RPI bagi seluruh ABK belum mampu dipenuhi oleh GPK. Pada standar proses, kondisi saat ini Sekolah Menengah Garuda Cendekia dalam kapasitasnya sebagai sekolah penyelenggara pendidikan inklusif belum mencapai standar proses dari kriteria Standar Penyelenggara Pendidikan Inklusif. Pelaksanaan kriteria Standar Penyelenggara Pendidikan Inklusif komponen penilaian standar proses memenuhi indikator pencapaian sebesar $78 \%$. Permasalahan yang muncul dalam pelaksanaan standar proses adalah kurangnya peran guru. Baik GPK maupun guru reguler dalam penyelenggaraan pendidikan inklusif.

Pelaksanaan kriteria Standar Penyelenggara Pendidikan Inklusif komponen penilaian standar kompetensi lulusan memenuhi indikator pencapaian sebesar 75,5 \%.Pelaksanaan kriteria Standar Penyelenggara Pendidikan Inklusif komponen penilaian standar penilaian memenuhi indikator pencapaian sebesar $74,14 \%$. Kesenjangan terletak pada guru kelas yang hanya melaporkan perkembangan ABK kepada orangtua murid 2 kali dalam setahun atau setiap pembagian rapor. Pelaksanaan kriteria Standar Penyelenggara Pendidikan Inklusif komponen penilaian standar sarana prasarana memenuhi indikator pencapaian sebesar 60,6\%. Kesenjangan terletak pada minimnya ketersediaan sarana prasarana dan alat peraga atau media pembelajaran di sekolah. Hal ini dapat disebabkan dengan kurangnya dana dan/atau kurangnya kecakapan sekolah dalam mengelola sarana prasarana yang dibutuhkan sekolah. Berkaitan dengan penggunaan dana, hal ini merujuk kepada pelaksanaan kriteria Standar Penyelenggara Pendidikan Inklusif komponen penilaian standar pembiayaan. Komponen penilaian standar pembiayaan memenuhi indikator pencapaian sebesar 30,25\%. Sekolah Menengah Garuda Cendekia tidak mendapatkan dana bantuan dari Dinas dan tidak mendapatkan dana tambahan dari luar atau dari lembaga swasta. Dikarenakan pihak sekolah tidak berjejaring atau dengan LSM atau lembaga swasta di luar Pemerintah.

Sekolah Menengah Garuda Cendekia dalam penyelenggaraan pendidikan inklusif telah mencapai nilai $61 \%$ (kategori baik). Artinya, masih ada Standar Penyelenggara Pendidikan Inklusif yang belum terpenuhi. Sehingga dapat dikatakan bahwa penyelenggaraan pendidikan inklusif bagi anak berkebutuhan khusus di Sekolah Menengah Garuda Cendekia masih terjadi kesenjangan (discrepancy). Serta dari kendala yang muncul, solusi yang dapat dilakukan adalah dengan memberikan pemahaman kepada guru kelas mengenai ABK dan pendidikan inklusif serta melakukan kerjasama antara guru kelas dengan GPK.

Dari hasil penelitian mengenai penyelenggaraan pendidikan inklusif bagi ABK di Sekolah Menengah Garuda Cendekia, dapat disarankan beberapa hal sebagai berikut.

1. Layanan yang diberikan sekolah terhadap ABK yang berkaitan dengan peserta didik lebih dimaksimalkan lagi yaitu identifikasi dan assesmen terhadap peserta didik. 
2. Sebagai sekolah penyelenggara pendidikan inklusif hendaknya menyusun kurikulum khusus anak berkebutuhan khusus yang sesuai dengan kebutuhan peserta didik agar layanan yang diberikan sekolah terhadap anak berkebutuhan khusus dapat maksimal.

3. Sebagai sekolah penyelenggara pendidikan inklusif hendaknya sekolah memfasilitasi adanya sarana pembelajaran berupa alat peraga ataupun sarana prasarana khusus untuk ABK agar dalam pemberian layanan kepada anak berkebutuhan khusus maksimal.

4. Sebagai sekolah penyelenggara pendidikan inklusif hendaknya sekolah berupaya memfasilitasi pendidik yang sesuai dengan kebutuhan sekolah yaitu dengan mengikutsertakan diklat tentang pendidikan inklusif.

5. Sebagai sekolah penyelenggara pendidikan inklusif hendaknya sekolah memberikan layanan berupa pengembangan life skills untuk peserta didik khususnya anak berkebutuhan khusus yang dapat digunakan sebagai bekal kehidupan dimasa mendatang.

6. Layanan yang diberikan sekolah kepada anak berkebutuhan khusus dari aspek kegiatan ekstrakurikuler lebih dikembangkan sesuai dengan jenis dan kebutuhan peserta didik.

7. Bagi Pemerintah Daerah, bagi pemerintah, khususnya Dinas Pendidikan Provinsi DKI Jakarta, bidang PLB, diharapkan untuk menyediakan GPK langsung dari SLB agar dapat menjadi pendamping konsultatif bagi guru reguler.

8. Bagi Kepala Sekolah, bagi kepala sekolah, diharapkan dapat meninjau ulang kebijakan pengulangan kelas bagi ABK. Selain itu, diharapkan kepala sekolah dapat mengadakan pertemuan orangtua $\mathrm{ABK}$ secara rutin guna melaporkan perkembangan peserta didik berkebutuhan khusus.

9. Guru Kelas dan GPK Sekolah Menengah Garuda Cendekia, bagi Sekolah Menengah Garuda Cendekia diharapkan untuk guru reguler bisa bekerjasama dengan GPK dalam merancang dan mengembangkan kurikulum yang sesuai dengan kebutuhan dan kemampuan ABK. Serta mengadakan dampingan konsultatif dari GPK kepada guru reguler.

Demikianlah saran penulis dalam peneltian ini, enulis berharap semoga penelitian ini segera dapat memberikan manfaat dan dapat digunakan sebagai acuan pelaksanaan pendidikan inklusif.

\section{DAFTAR PUSTAKA}

Ahmad Toha Muslim \& M. Sugiamin. (1996). Ortopedi dalam Pendidikan Anak Tunadaksa. Bandung: Depdikbud.

Basrowi dan Suwandi. (2008). Memahami Penelitian Kualitatif. Jakarta : Rineka Cipta.

Budiyanto. (2005). Pengantar Pendidikan Inklusif Berbasis Budaya Lokal.Jakarta.

Dedy Kustawan. (2012). Pendidikan Inklusif dan Upaya Implementasinya. Jakarta: PT Luxima Metro Media.

Eko putro Widoyoko. (2009). Evaluasi Program Pembelajaran Panduan Praktis Bagi Pendidik dan Calon Pendidik. Yogyakarta: Pustaka Pelajar.

Endang Mulyatiningsih. (2012). Metode Penelitian Terapan Bidang Pendidikan. Yogyakarta: Alfabeta.

Farida Yusuf Tayibnapsis. (1989). Evaluasi Program. Jakarta : Rineka Cipta. 
Evaluasi Implementasi Standar Nasional Pendidikan Pada Pendidikan Inklusif Di Sekolah Menengah Garuda Cendißia

(2000). Evaluasi Program. Jakarta : Rineka Cipta.

Hallahan, D.P., Kauffman, J.M. \& Pullen, P. C. 2009. Exceptional Learners An Introduction to Special Education. New York : Pearson.

Kemendiknas. 2010. Modul Pelatihan Pendidikan Nasional. Cetakan pertama.

Lay Kekeh Marthan. 2007. Manajemen Pendidikan Inklusif. Jakarta : DIRJEN DIKTI.

Nani Triani. 2012. Panduan Asesmen Anak Berkebutuhan Khusus. Jakarta : PT Luxima Metro Media.

Roger A. Pierangelo \& George A. Giuliani. 2013. Assessment in Special Education: A Practical Approach. Singapore : Pearson.

Sugiyono. 2013. Metode Penelitian Pendidikan. Bandung : Alfabeta.

Suharsimi Arikunto. 2009. Dasar-dasar Evaluasi Pendidikan. Jakarta : Aneka Cipta

Suharsimi Arikunto \& Cepi Safrudin. 2014. Evaluasi Program Pendidikan: Pedoman Teoritis Praktis Bagi Mahasiswa dan Praktisi Pendidikan. Edisi Kedua. Jakarta : PT. Bumi Aksara.

Sutjihati Soemantri. 2007. Psikologi Anak Luar Biasa. Bandung : PT. Refika Aditama.

Tarmansyah. 2007. Inklusi Pendidikan Untuk Semua. Jakarta : Depdiknas.

Tim ASB. 2011. Panduan I : Kriteria Standar Penyelenggara Pendidikan Inklusif Sekolah Inklusi. Yogyakarta : Dinas Dikpora DIY dan ASB Indonesia.

Website:

https://kelembagaan.ristekdikti.go.id/wpcontent/uploads/2016/08/UU_no_20_th_2

003.pdf diakses pada tanggal 11 November 2018 pukul 12.35

http://luk.staff.ugm.ac.id/atur/PP17-2010Lengkap.pdf diakses pada tanggal 11

November 2018 pukul 12.50

https://kelembagaan.ristekdikti.go.id/wp-content/uploads/2016/11/Permen-No.-

70-2009-tentang-pendidiian-inklusif-memiliki-kelainan-kecerdasan.pdf

diakses pada tanggal 11 November 2018 pukul 12.57

http://www.bpkp.go.id/uu/filedownload/2/41/311.bpkpdiakses pada tanggal 11

November 2018 pukul 13.37 